\title{
Development of Corporate Governance Performance INDICATORS FOR CZECH MANUFACTURING COMPANIES
}

\section{Marie Pavláková Dočekalová ${ }^{1}$, Alena Kocmanová ${ }^{2}$, Jiří Koleňák ${ }^{3}$}

\begin{abstract}
Effective corporate governance is a key element in achieving long-term success for any company. The codes of conduct that corporate governance adopts directly determine the sustainability of business activities. With this in mind, this paper aims to demonstrate the results of research that identifies a set of key indicators of corporate governance performance. The presented research is quantitative. In order to identify key performance indicators, factor analysis was employed. It was found that corporate governance performance is influenced by two factors. For the first factor, the relationship between corporate governance and stakeholders is measured by key indicators: percentage of women within CG, contributions to political parties, politicians and related institutions and number of complaints received from stakeholders. The second factor, strategy \& compliance, is generated from the following: percentage of strategic objectives met and total number of sanctions for breaching the law. This research aims to assist both academic and corporate practitioners who want to improve corporate governance performance and, through the use of key performance indicators, support the transparency and sustainability of their business.
\end{abstract}

\section{Keywords}

Corporate governance, key performance indicators, sustainability, factor analysis.

\section{Introduction}

With the financial and economic crisis, the need to adopt stricter economic, financial and accounting rules has become imperative. Companies should learn from the crisis and not just limit corporate performance assessment to the pure revision of their financial

\footnotetext{
${ }^{1}$ Faculty of Business and Management of Brno University of Technology, Kolejní 2906/4, 61200 Brno, Czech Republic. E-mail: docekalova@ fbm.vutbr.cz.

${ }^{2}$ Faculty of Business and Management of Brno University of Technology, Kolejní 2906/4, 61200 Brno, Czech Republic. E-mail: kocmanova@ fbm.vutbr.cz.

${ }^{3}$ Newton College, Politických vězňů 10, 110 00, Praha 1, Czech Republic. E-mail: jiri.kolenak@newtoncollege.cz.
} 
performance. As stated by the European Commission (2011) in its Green Paper, corporate governance is intended to eliminate a focus on short-term interests and inadequate risk taking. We refer to corporate governance in cases where the management of a company is separate from its owners (Růčková, 2008).

Investors and other corporate stakeholders are becoming increasingly interested in the environmental, social and corporate governance (ESG) aspects of entrepreneurship. These three nonfinancial factors widen the traditional perception of company performance beyond the realm of economic performance and management of these aspects introduces transparency and sustainability (Kocmanová and Dočekalová, 2012; Hřebíček, Soukopová, Štencl, Trenz, 2011). The aim of this article is to define key performance indicators (KPIs) of corporate governance (CG) in connection with corporate sustainability.

\section{Theoretical Approach to Corporate Governance}

The Committee on the Financial Aspects of Corporate Governance $\left(1992^{4}\right.$ in Kavalîr, 2005) defines corporate governance as "the system by which companies are directed and controlled. Boards of directors are responsible for the governance of their companies. The shareholders' role in governance is to appoint the directors and the auditors and to satisfy themselves that an appropriate governance structure is in place. The responsibilities of the board include setting the company's strategic aims, providing the leadership to put them into effect, supervising the management of the business and reporting to shareholders on their stewardship. The board's actions are subject to laws, regulations and the shareholders in general meeting."

Corporate governance is a key element of economic performance. According to Klírová (2001), the task of corporate governance is to "... evaluate economic performance from a broader perspective than the executive, i.e. consider the interests of all stakeholders and act accordingly in order to influence the creation of the business strategy and its implementation to meet those needs". Ayuso and Argandona (2007) emphasize that the broader meaning of corporate governance includes relationships with a wide spectrum of stakeholders both internal (employees) and external (customers, suppliers, etc.).

The OECD has created a general set of standards and guidelines of corporate governance - the OECD Principles of Corporate Governance.

The main principles of the OECD (2004) emphasize:

- providing an effective legal and regulatory framework for due governance,

- protecting and facilitating the exercise of shareholder rights;

- equal treatment of shareholders,

- reinforced shareholder rights,

- the accessibility and transparency of information concerning a company, especially as regards its financial position, activities, and ownership and management,

- ensuring the responsibility of the supervisory board.

\footnotetext{
${ }^{4}$ Cadbury Report.
} 
The OECD sees the most serious problems in the insufficient transparency of companies and their actions. The Czech Corporate Governance Code is based on the OECD Principles mentioned above.

The so-called Green Paper - the EU corporate governance framework is a significant document within the European economic area - was created by the European Commission. This document defines what needs to be improved within the sphere of EU company operations. It focuses on three key areas:

- the board of directors,

- shareholders engagement,

- following and applying the principles of corporate governance according to the 'comply or explain' approach.

Based on the European Parliament and Council Directive 2006/46/EC of June 14, 2006, companies whose securities are admitted to trading on a regulated market should be obliged to disclose an annual corporate governance statement as a specific and clearly identifiable section of the annual report. This would provide the shareholders with easily accessible key information about the corporate governance practices being applied, including a description of the main features of any existing risk management systems and internal controls in relation to the financial reporting process. Also, companies should state what principles they have decided to follow.

Corporate governance theory can be divided, based on whose interests the company should prioritize, into stockholder theory and stakeholder theory. These two theories have gradually been broadened. According to stockholder theory, the primary goal of companies is to satisfy the needs of the shareholders. Within this theory are two more theories divided by their approach towards conflict between the interests of shareholders and managers. According to agency theory, the interests of shareholders and those of managers are conflicting, because the shareholder's goal is to maximize their wealth, while the manager's goal is to maximize their own income and benefits, which is not necessarily beneficial for the shareholders. The stewardship theory is based on psychology and sociology and considers the interests of these two groups to be identical. The benefit of the managers provided by good management and acting in accordance with the interests of the shareholders is better than the benefit gained by meeting their own material needs (Donaldson and Davis, 1991; Růčková, 2008).

Criticism of the stockholder theory brought about the stakeholder theory, which introduces the relationship between a company and other stakeholders. This theory introduced the idea of the social responsibility of companies (Solomon, 2007). The stakeholder theory states that the main goal of a company is to maximize profit, but this goal is supposed to be met by satisfying the needs of the stakeholders. The classical version of the stakeholder theory states that the primary goal is to maximize the satisfaction of the needs of all the stakeholders. From this point of view, a company is no longer considered to be an investment of the shareholders, but is instead an investment of all stakeholders (Malý, Theodor and Peklo, 2002; Růčková, 2008). According to extreme adherents of 
the traditional stakeholder theory, not only traditional stakeholders are to be considered: future generations and the environment are stakeholders as well (Solomon, 2007).

\section{Corporate Governance Models}

There are two different models of corporate governance. The difference can be demonstrated by means of two different definitions. Shleifer and Vishny (1997) define CG as a way in which suppliers of finance (mainly shareholders) to corporations assure themselves of getting a return on their investment. Demb and Neubauer (1992, in Kavalîr, 2005) define CG as a process by which companies respond to the rights and wishes of stakeholders.

The Anglo-American model (outsider model, shareholders model, monistic model) emphasizes shareholders' interests. It is a one chamber system of control with two main authorities. The board of directors is an authority which includes managers (executive directors) who are the executive authority and experts invited externally (nonexecutive independent directors). In Europe, this model is mainly used in Great Britain and Spain. The Continental European model (insider model, stakeholder model, dualistic model) prioritizes the interests of the stakeholders. This model separates the responsibility for managing a company to the management board functioning as top management and including only executive members or a combination of executive and nonexecutive members and a supervisory board consisting of shareholders and other members, e.g. bankers, employees, scientists, etc. This system is used in, for example, Germany and Japan (Kavalîr, 2005; Růčková, 2008).

Czech corporate governance is mainly defined in Act. No. 90/2012 Coll., on Commercial Companies and Cooperatives.

\section{Corporate Governance Performance Indicators}

It is not easy to find a definition of corporate governance performance. The literature mentions the effectiveness of corporate governance rather than its performance, while the effectiveness of corporate governance is understood to be its influence on financial performance (Jungman, 2006).

Corporate governance is an element directly influencing transparency, responsibility and sustainability within a company and therefore within the whole economic system. Many international institutions are attempting to define corporate governance indicators in relation to company sustainability. The corporate governance performance indicators are usually related to these areas:

- composition and rewarding system of a supervisory board,

- corruption,

- engagement of stakeholders,

- economic competition approach,

- political lobby,

- transparency, reporting and ethical code. 
International organizations that deal with the issue of corporate sustainability suggest measuring CG performance according to the criteria presented in Table 1.

Table 1: Corporate governance performance indicators

\begin{tabular}{|c|c|c|c|}
\hline $\begin{array}{l}\text { International } \\
\text { Federation of } \\
\text { Accountants (IFAC) }\end{array}$ & $\begin{array}{l}\text { German Association for } \\
\text { Financial Analysis and } \\
\text { Asset } \\
\text { Management }{ }^{5} \text { (DVFA) }\end{array}$ & $\begin{array}{l}\text { European Academy of } \\
\text { Business in Society } \\
\text { (EABIS) }\end{array}$ & $\begin{array}{l}\text { United Nations } \\
\text { Conference on Trade } \\
\text { and Development } \\
\text { (UNCTAD) }\end{array}$ \\
\hline $\begin{array}{l}\text { Board composition } \\
\text { Board duration } \\
\text { Board remuneration } \\
\text { Percent women at } \\
\text { board level } \\
\text { Indication of risk } \\
\text { management policies } \\
\text { and implementation } \\
\text { Stakeholder } \\
\text { engagement } \\
\text { Conduct, litigation } \\
\text { risks, corruption }\end{array}$ & $\begin{array}{l}\text { Contributions to } \\
\text { political parties } \\
\text { Anti-competitive } \\
\text { behaviour } \\
\text { Corruption } \\
\text { Litigation payments }\end{array}$ & $\begin{array}{l}\text { Ethical code } \\
\text { deployment } \\
\text { Board composition } \\
\text { Equality \& diversity } \\
\text { Reporting \& } \\
\text { transparency } \\
\text { Shareholder interests } \\
\text { Anticorruption policy }\end{array}$ & $\begin{array}{l}\text { Payments to } \\
\text { Government } \\
\text { Voluntary } \\
\text { contributions to civil } \\
\text { society } \\
\text { Number of } \\
\text { convictions for } \\
\text { violations of } \\
\text { corruption related } \\
\text { laws or regulations } \\
\text { and amount of fines } \\
\text { paid }\end{array}$ \\
\hline
\end{tabular}

Source: IFAC (2012), DVFA (2007), Cranfield School of Management (2009), UNCTAD (2008)

\section{Methodology}

A search of the literature proved that there is a need to include an evaluation of corporate governance performance in alternative corporate performance systems. The aim of this article is to define those indicators measuring corporate governance performance which will give the best evidence of the responsibility of corporate governance in relation to company sustainability. The research was carried out in the third quarter of 2013. The research tool was a questionnaire. The aim of this questionnaire was to verify the suggested CG performance indicators. The research was focused on large manufacturing industry companies belonging to the group CZ - NACE 27.1 Manufacture of electric motors, generators, transformers and electricity distribution and control apparatus. The basic set consists of 32 companies. The response rate was $72 \%$. The questionnaire was based on evaluating the significance of the CG performance indicators, i.e. how much the factors of these indicators support the corporate sustainability performance. A rating method was used. Experts, mainly CEOs, expressed their opinions on the basis of a predetermined scale $<0 ; 10>$. The research sample is described in Table 2 .

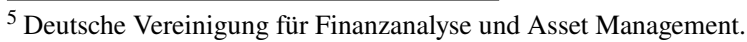


Table 2: Research sample

\begin{tabular}{|l|r|r|}
\hline Criteria & N & \% \\
\hline Majority Owner & & \\
Domestic subject & 8 & 34.8 \\
International subject & 15 & 65.2 \\
Legal form & & \\
Stock company & 4 & 17.4 \\
Ltd. & 19 & 82.6 \\
Number of employees in 2012 & & \\
250-750 & 13 & 56.5 \\
$751-1250$ & 4 & 17.4 \\
1251-1750 & 2 & 8.7 \\
1751-2250 & 2 & 8.7 \\
More than 2251 & 2 & 8.7 \\
\hline
\end{tabular}

Source: own research

To select key performance indicators from the basic set of indicators, correlation and factor analyses were applied. The purpose of the correlation analysis is multicollinearity detection and the removal of redundant key indicators from the model. High values of pair correlation coefficients, i.e. $|r|>0.8$ suggest multicollinearity. To detect multicollinearity, the variance inflation factor was also used (Variance Inflation Factor, VIF), which is easily detected from an inversion matrix of the correlation matrix. VIF are diagonal elements of such an inversion matrix (Clark, 2004). The indicator with the higher VIF value was removed from the model. Factor analysis is based on a simple idea to describe the behaviour of a set of variables by using a smaller number of new variables - factors - and via theses come to conclusions about the mutual dependence of the original variables.

The factor model analysis is as follows:

$$
\begin{aligned}
x_{1} & =\alpha_{11} F_{1}+\alpha_{12} F_{2}+\ldots+\alpha_{1 m} F_{m}+e_{1} \\
x_{2} & =\alpha_{21} F_{1}+\alpha_{22} F_{2}+\ldots+\alpha_{2 m} F_{m}+e_{2} \\
\ldots & \\
x_{Q} & =\alpha_{Q 1} F_{1}+\alpha_{Q 2} F_{2}+\ldots+\alpha Q m F_{m}+e_{q}
\end{aligned}
$$

where:

$x_{i}(i=1, \ldots, Q)$ is the original set of variables (variables are standardized, i.e. zero mean value and unit distribution),

$\alpha_{i 1}, \alpha_{i 2}, \ldots, \alpha_{i m}$ are factor loadings (factor loadings are between -1 and +1 and can be interpreted as correlation coefficients between the variables and factors.,

$F_{1}, F_{2}, \ldots, F_{m}$ is $\mathrm{m}$ non-correlated standardized factors,

$e_{i}$ is specific (unique, error, residual) part of the variable $x_{i}$ (OECD, 2008; Škaloudová, 2010).

Before the computation it is useful to decide whether the factor analysis is worth carrying out, i.e. whether the correlations of the variables are possible to explain by factors. Kaiser - Meyer - Olkin statistics (KMO statistics) is used for this as well as Barlett's test of sphericity. KMO is based on comparing the values of pair and partial correlation 
coefficients and reaches values between 0 and 1 . KMO statistics values are possible to interpret as follows: $0.90-1.00$ using factor analysis is excellent, $0.80-0.89$ very good, $0.70-0.79$ medium level of usefulness, $0.60-0.69$ average, $0.50-0.59$ poor and $0.00-0.49$ not acceptable. Bartlett's test of sphericity tests a zero hypothesis that the correlation matrix of the variables is unit-based, i.e. correlation coefficients of the variables equal zero and therefore the condition of mutual dependence of variables is not met, which prevents applying the factor analysis (Škaloudová, 2010).

An important decision has to be made when applying factor analysis and that is the number of factors. This step significantly influences the solution and interpretation of factor analysis results. To set the number of factors, the so-called Kaiser criterion is used. According to this rule, only those factors with eigenvalues greater than one are retained. The number of factors can also be defined from graphic presentation of eigenvalues of individual factors by using a scree plot. The borderline marking the suitable number of factors lies where the numerical drop between two factors is the most significant. The number of factors can also be set heuristically.

The inner reliability of the suggested KPIs was then checked by applying Cronbach's alpha. Inner reliability means that indicators measuring the same phenomenon should have positive mutual correlations. For this purpose, Cronbach's alpha or reliability coefficient or consistency coefficient is applied. Cronbach's alpha reaches values of 0 to 1 . Cronbach's alpha is computed by the following formula:

$$
\alpha=\frac{K * C / V}{1-(K-1)(C / V)}
$$

where:

$C$ is the average inter-item covariance among the variables,

$V$ is the average variance of all the variables.

For standardized Cronbach's alpha the formula is:

$$
\alpha=\frac{K * R}{1-(K-1)(R)}
$$

where:

$R$ is the average of all the correlation coefficients of the variables.

\section{Research results}

Indicators of corporate governance were defined through a synthesis of knowledge gained in the pre-research stage (results published in Kocmanová and Šimberová, 2012) and the approaches of those organisations mentioned in Table 1.

The fulfilment of strategic objectives is measured by Corporate Governance Performance Indicator CG1 - Strategy. Indicator CG2 - Corporate Governance Effectiveness is connected to the composition, rewarding and qualification of CG. This indicator was adopted from IFAC. The rejection of corruption and compliance with legislation are important 
elements of the sustainability and responsibility of CG and therefore the basic set also includes indicator CG3 - Compliance. Indicator CG4 - political involvement and paying public officers and institutions - was created on the basis of IFAC, DVFA and UNCTAD approaches. Considering the risk of corruption, the approaches all recommend measuring and reporting these contributions. Indicator CG5 - Relationships with stakeholders is defined by the number of complaints received from the company stakeholders.

Table 3: Basic set of Corporate Governance Performance Indicators

\begin{tabular}{|l|l|}
\hline Indicator & Performance indicator \\
\hline CG1 - Strategy & $\mathrm{PI}_{1}$ Percentage of strategic objectives met \\
\hline & $\mathrm{PI}_{2}$ CG composition \\
& $\mathrm{PI}_{3}$ Total annual salaries and bonuses ${ }^{7}$ of CG members \\
& $\mathrm{PI}_{4}$ Fluctuation of CG \\
& $\mathrm{PI}_{5}$ Percentage of women within CG \\
& $\mathrm{PI}_{6}$ Qualification and skills of CG members - managerial and \\
& economical education \\
& $\mathrm{PI}_{7}$ Qualification and skills of CG members - education in the \\
& field of business \\
\hline & $\mathrm{PI}_{8}$ Number of convictions for violations of laws or regulations \\
& relating to corruption \\
& $\mathrm{PI}_{9}$ Total number of sanctions for anticompetitive behaviour \\
& $\mathrm{PI}_{10}$ Total number of sanctions for breaching the law \\
\hline CG3 - Compliance & $\mathrm{PI}_{11}$ Contributions to political parties, politicians and related \\
\hline public officers and institutions & institutions \\
\hline CG5 - Relationships with stakeholders & $\mathrm{PI}_{12}$ Number of complaints received from stakeholders \\
\hline
\end{tabular}

Source: own research

To verify the relevancy of the suggested performance indicators and to obtain basic knowledge about their influence on corporate performance, a questionnaire was carried out. The respondents were managers of companies (mostly CEOs).

The questionnaire proved the significant impact of effective CG on a long-term success and a performance of a company. $74 \%$ of respondents stated that CG has crucial influence and $26 \%$ confirmed significant impact. These findings are in accordance with the conclusions of authors Gompers, Ishii and Metrick (2001), on the other hand, Heracleous (2001) says that corporate governance "best practices" have no significant impact on corporate performance.

The relevance and importance of CG performance indicators was evaluated on the basis of a predetermined scale $<0 ; 10>$. Large companies in manufacturing industry perceive the following as key success factors: the reaching of strategic objectives, good relationships with all stakeholders, responsible behaviour, i.e. compliance with rules and laws, see graph 1 . The qualifications and skills of the CG members are also important. Managerial and economical education is slightly more important than technical education in the field of business. Contributions to politicians and related institutions are perceived as unimportant.

\footnotetext{
${ }^{6}$ The goal of this indicator is to define the relationship (i.e. dependence or independence) of the executive board on other control authorities of the company.

${ }^{7}$ Including shares.
} 
Also, gender equality is seen by Czech companies as unimportant. This is in contrast with EU policy, which urges gender balance in the management of both private and public organizations.

\section{Graph 1: Importance of corporate governance performance indicators}

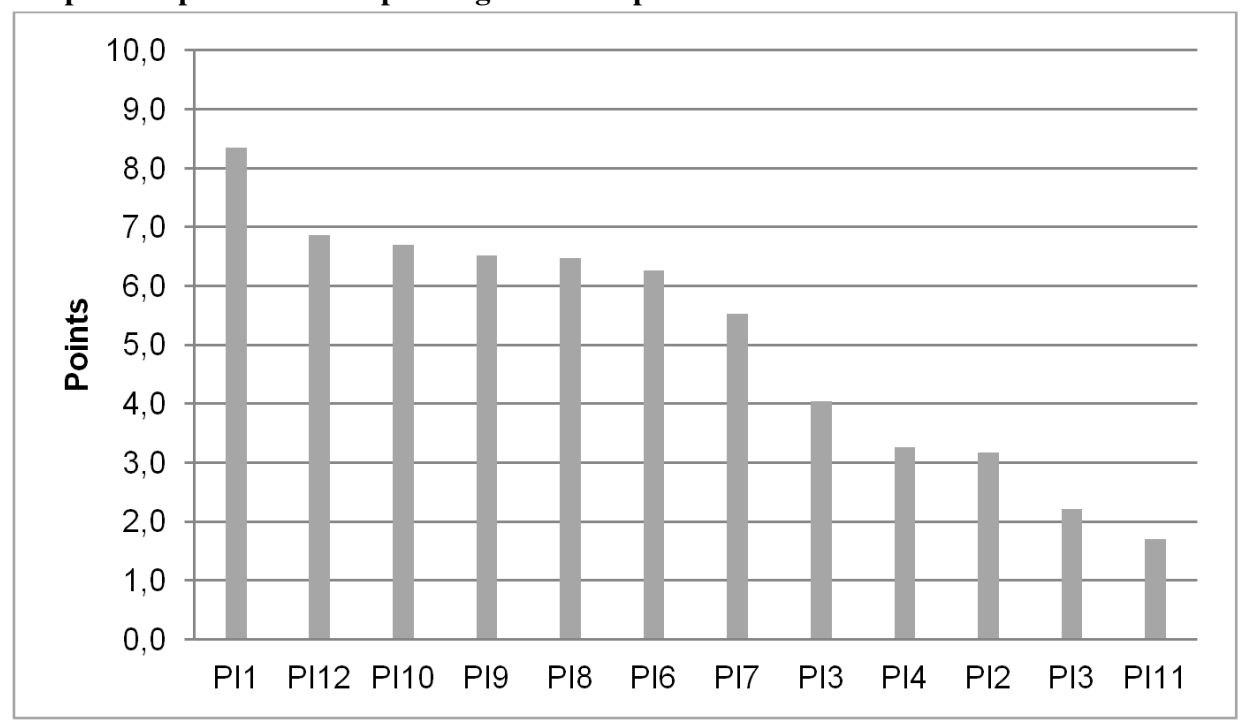

Source: own research

The first step in processing the data was a quality check carried out in order to find out whether there were erroneous, missing or distant values in the data. The following statistic measures were computed in order to get the basic knowledge of key indicators:

- measures of central tendency (arithmetic mean $\bar{x}$ and median $\tilde{x}$ ),

- measures of variability (range $R$, standard deviation $s$ and variation coefficient $V x)$,

- measures of shape (skewness skew and kurtosis kurt).

Selected descriptive characteristics of the CG performance indicators are listed in Table 4. The highest value of variation coefficient was shown in contributions to political parties, politicians and related institutions $(V x=154.4 \%)$. This indicator is also the least significant one $(\bar{x}=1.7$ a $\tilde{x}=1.0)$. The lowest variability was shown in the percentage of strategic objectives met indicator $(V x=30.6 \%)$. This indicator is perceived by companies as the most significant one when it comes to success and performance. This indicator is also the most asymmetrical one. Higher values are more common than lower ones $($ skew $=-2.1)$. At the same time, this is a range with the highest coefficient of sharpness $(k u r t=4.5)$ and therefore most of the values are to be found near the mean value $(\bar{x}=8.3$ a $\tilde{x}=9.0)$. Fluctuation of $\mathrm{CG}$ is an example of normal distribution $($ kurt $=0.0)$. 
Table 4: Descriptive characteristics of corporate governance performance indicators

\begin{tabular}{|c|c|c|c|c|c|c|c|c|c|}
\hline Indicator & $R$ & Min. & Max. & $\bar{x}$ & $\tilde{x}$ & $s$ & $V x(\%)$ & skew & kurt \\
\hline $\begin{array}{l}\text { Percentage of strategic objecti- } \\
\text { ves met }\end{array}$ & 10.0 & 0.0 & 10.0 & 8.3 & 9.0 & 2.6 & 30.6 & -2.1 & 4.5 \\
\hline CG composition & 8.0 & 0.0 & 8.0 & 3.2 & 3.0 & 3.0 & 95.3 & 0.6 & -1.1 \\
\hline $\begin{array}{l}\text { Total annual salaries and bo- } \\
\text { nuses of CG members }\end{array}$ & 9.0 & 0.0 & 9.0 & 4.0 & 4.0 & 1.9 & 46.9 & 0.9 & 2.2 \\
\hline Fluctuation of CG & 10.0 & 0.0 & 10.0 & 3.3 & 2.0 & 3.4 & 103.5 & 1.1 & 0.0 \\
\hline $\begin{array}{l}\text { Percentage of women within } \\
\text { CG }\end{array}$ & 9.0 & 0.0 & 9.0 & 2.2 & 1.0 & 2.4 & 106.2 & 1.6 & 2.3 \\
\hline $\begin{array}{l}\text { Qualification and skills of CG } \\
\text { members - managerial and eco- } \\
\text { nomical education }\end{array}$ & 9.0 & 0.0 & 9.0 & 6.3 & 7.0 & 2.7 & 43.7 & -1.1 & 0.6 \\
\hline $\begin{array}{l}\text { Qualification and skills of CG } \\
\text { members - education in the } \\
\text { field of business }\end{array}$ & 9.0 & 0.0 & 9.0 & 5.5 & 6.0 & 2.5 & 45.6 & -1.0 & 0.5 \\
\hline $\begin{array}{l}\text { Number of convictions for vi- } \\
\text { olations of laws or regulations } \\
\text { relating to corruption }\end{array}$ & 10.0 & 0.0 & 10.0 & 6.5 & 7.0 & 2.9 & 44.1 & -0.5 & -0.6 \\
\hline $\begin{array}{l}\text { Total number of sanctions for } \\
\text { anticompetitive behaviour }\end{array}$ & 9.0 & 1.0 & 10.0 & 6.5 & 7.0 & 3.1 & 48.0 & -0.3 & -1.4 \\
\hline $\begin{array}{l}\text { Contributions to political par- } \\
\text { ties, politicians and related in- } \\
\text { stitutions }\end{array}$ & 9.0 & 0.0 & 9.0 & 1.7 & 1.0 & 2.6 & 154.4 & 1.7 & 1.9 \\
\hline $\begin{array}{l}\text { Number of complaints received } \\
\text { from stakeholders }\end{array}$ & 10.0 & 0.0 & 10.0 & 6.9 & 7.0 & 2.6 & 37.6 & -1.0 & 1.0 \\
\hline $\begin{array}{l}\text { Total number of sanctions for } \\
\text { breaching the law }\end{array}$ & 10.0 & 0.0 & 10.0 & 6.7 & 8.0 & 3.0 & 44.2 & -0.5 & -0.7 \\
\hline
\end{tabular}

Source: own research

\section{Identification of Key Corporate Governance Performance Indicators}

The selection of the key performance indicators is carried out in two steps. First, the correlation analysis identifies the key indicators that provide approximately the same information about a corporate's performance and success. The redundant key indicators are eliminated and factor analysis follows next. Its goal is the further reduction of the number of the key indicators.

Within corporate governance, the highest correlation can be found between Qualification and skills of CG members - managerial and economical education and Qualification and skills of CG members - education in the field of business $(r=0.916)$, Total number of sanctions for anticompetitive behaviour and Number of convictions for violations of laws or regulations relating to corruption $(r=0.895)$, Fluctuation of CG and CG composition $(r=0.877)$. Table 5 shows all the values of pair correlation coefficients $|r|>0.8$. 
Table 5: KPIs reduction - correlation analysis

\begin{tabular}{|c|c|}
\hline Performance indicators & $\begin{array}{c}\text { Correlation } \\
\text { coefficient }\end{array}$ \\
\hline Fluctuation of CG & \multirow{2}{*}{0.877} \\
\hline CG composition & \\
\hline Percentage of women within CG & \multirow{2}{*}{0.864} \\
\hline Total annual salaries and bonuses of CG members & \\
\hline Qualification and skills of CG members - education in the field of business & \multirow{2}{*}{0.916} \\
\hline Qualification and skills of CG members - managerial and economical education & \\
\hline Total number of sanctions for breaching the law & \multirow{2}{*}{0.853} \\
\hline Qualification and skills of CG members - managerial and economical education & \\
\hline Total number of sanctions for anticompetitive behaviour & 0.895 \\
\hline
\end{tabular}

Source: own research

After the evaluation of the pair correlation coefficients and values of the Variance Inflation Factor, the following performance indicators were removed: Fluctuation of CG, Total annual salaries and bonuses of CG members, Qualification and skills of CG members - managerial and economical education, Qualification and skills of CG members education in the field of business, number of corruption law breaches. The reduced set of CG performance indicators includes seven indicators: Percentage of strategic objectives met, CG composition, Percentage of women within CG, Total number of sanctions for anticompetitive behaviour, Total number of sanctions for breaching the law, Contributions to political parties, politicians and related institutions and Number of complaints received from stakeholders.

The suitability of factor analysis was checked by the Kaiser - Meyer - Olkin statistics (KMO) and Bartlett's sphericity test. The KMO of the individual indicators from the antiimage matrix reach sufficient values with the exception of the indicator Total number of sanctions for anticompetitive behaviour $(\mathrm{KMO}=0.497)$. Once this indicator was eliminated, the KMO statistics rise from 0.689 to 0.775 . The Bartlett's sphericity test confirmed the factor analysis application to be beneficial and the factor analysis application condition, i.e. the mutual dependence of the variables, was met.

Table 6: KMO statistics and Bartlett's sphericity test

\begin{tabular}{|l|lr|}
\hline \multicolumn{2}{|c|}{ Kaiser - Meyer - Olkinova statistics } & 0.775 \\
\hline \multirow{3}{*}{ Bartlett's sphericity test } & Approx. chi-sq. & 60.002 \\
& df & 15 \\
& Sig. & 0.000 \\
\hline
\end{tabular}

Source: own research

Table 7 lists communalities, i.e. part of variability of the variables explained by extracted factors. The variability of CG performance indicators is possible to explain by factors of approx. $76 \%$. Variability of percentage of strategic objectives met is best explained $(83.9 \%)$. The least explained is Number of complaints received from stakeholders $(62.7 \%)$. 
Table 7: Communalities of CG performance indicators

\begin{tabular}{|l|c|c|}
\hline Performance indicators & Initial & Extraction \\
\hline Percentage of strategic objectives met & 1.000 & 0.839 \\
CG composition & 1.000 & 0.702 \\
Percentage of women within CG & 1.000 & 0.721 \\
Total number of sanctions for breaching the law & 1.000 & 0.839 \\
Contributions to political parties, politicians and related institutions & 1.000 & 0.817 \\
Total number of sanctions for breaching the law & 1.000 & 0.627 \\
\hline
\end{tabular}

Source: own research

Six extracted components explain the total variance of the original variables. The first component defines $38.43 \%$ of the variance, the second component defines $37.31 \%$ of the variance and together they explain $75.74 \%$ of the variance of the performance indicators (see Table 8). According to Kaiser's rule, two components should be used for further analysis, because their eigenvalue is higher than 1 . Graph $2-$ Scree plot shows all the extracted components with their eigenvalues. The graph clearly shows the turn between the first and the second component. It would therefore be sufficient to consider only one component. However, Kaiser's rule approach is more convenient, considering the total explained variance.

Table 8: Eigenvalues and percentage of explained distribution

\begin{tabular}{|c|ccc|ccc|}
\hline Component & Eigenvalue & $\begin{array}{c}\text { \% of explained } \\
\text { variance }\end{array}$ & Cumulated \% & $\begin{array}{c}\text { Eigenvalue after } \\
\text { rotation }\end{array}$ & $\begin{array}{c}\text { \% of explained Cumulated \% } \\
\text { variance }\end{array}$ & C \\
\hline 1 & 3.526 & 58.759 & 58.759 & 2.305 & 38.425 & 38.425 \\
2 & 1.019 & 16.976 & 75.735 & 2.239 & 37.311 & 75.735 \\
3 & 0.610 & 10.165 & 85.900 & & & \\
4 & 0.386 & 6.437 & 92.337 & & & \\
5 & 0.264 & 4.407 & 96.744 & & & \\
6 & 0.195 & 3.256 & 100.000 & & & \\
\hline
\end{tabular}

Source: own research

\section{Graph 2: Scree plot}

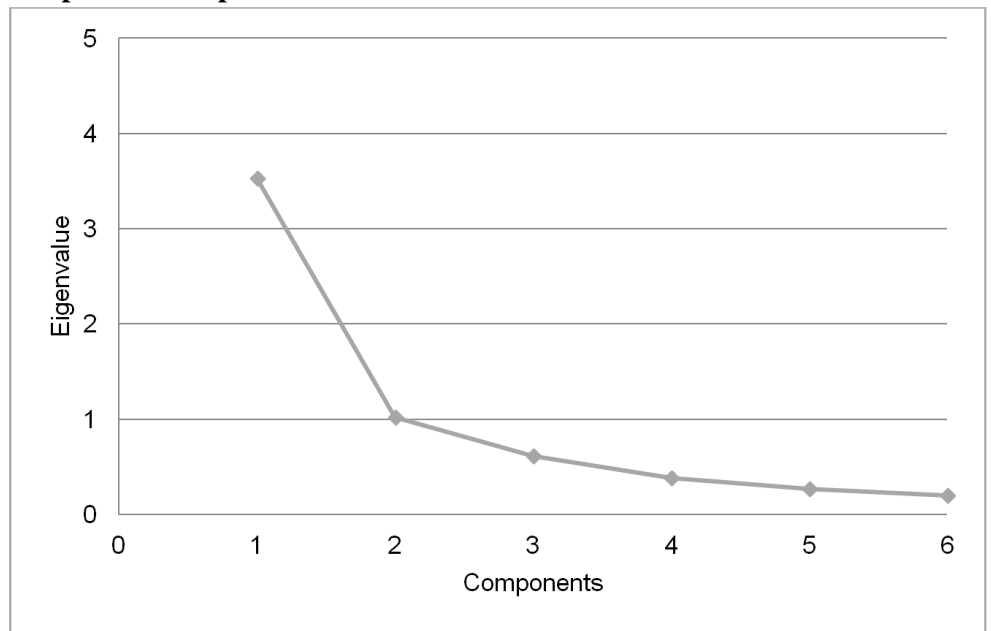

Source: own research 
The Varimax factor rotation contributed to a solution which was easier to interpret. The factor solution matrix neglects small factor weight, i.e. factor weight smaller than 0.3 . The key performance indicators selection is based on their component correlation and only the ones with the factor weight higher than 0.7 , which can be considered sufficiently high, are considered key. In the first main component the following key performance indicators create the first component, named Relationship of Corporate Governance and stakeholders: Percentage of women within CG, Contributions to political parties, politicians and related institutions and Number of complaints received from stakeholders. The second component is created by these KPIs: Percentage of strategic objectives met and Total number of sanctions for breaching the law. The second component is called Strategy \& Compliance.

\section{Table 9: Factor solutions matrix}

\begin{tabular}{|l|rr|rc|}
\hline \multirow{2}{*}{ KPI } & \multicolumn{2}{|c|}{ Component } & \multicolumn{2}{c|}{ Component - rotated } \\
\cline { 2 - 5 } & $\mathbf{1}$ & $\mathbf{2}$ & $\mathbf{1}$ & $\mathbf{2}$ \\
\hline Percentage of strategic objectives met & 0.737 & -0.544 & & $\mathbf{0 . 9 0 4}$ \\
CG composition & 0.825 & & 0.489 & 0.680 \\
Percentage of women within CG & 0.783 & 0.327 & $\mathbf{0 . 7 9 0}$ & 0.312 \\
Total number of sanctions for breaching the law & 0.791 & -0.462 & & $\mathbf{0 . 8 8 3}$ \\
Contributions to political parties, politicians and related & 0.799 & 0.422 & $\mathbf{0 . 8 6 7}$ & \\
institutions & & & & \\
Number of complaints received from stakeholders & 0.651 & 0.450 & $\mathbf{0 . 7 8 1}$ \\
\hline
\end{tabular}

Source: own research

The reliability of the corporate governance KPIs was verified by Cronbach's alpha $(\alpha)$, which exceeds the recommended limit of 0.7 .

\section{Table 10: Set of CG KPIs}

\begin{tabular}{|l|l|}
\hline $\begin{array}{c}\text { Relationship of Corporate Governance } \\
\text { and stakeholders }\end{array}$ & \multicolumn{1}{c|}{ Strategy \& Compliance } \\
\hline $\begin{array}{l}\text { - Contributions to political parties, politicians and } \\
\text { related institutions } \\
\text { - Number of complaints received from stakeholders } \\
\text { - Percentage of women within CG }\end{array}$ & $\begin{array}{l}\text { - Percentage of strategic objectives met } \\
\text { Total number of sanctions for breaching the law }\end{array}$ \\
\hline$\alpha=0.806$ & $\alpha=0.839$ \\
\hline
\end{tabular}

Source: own research

Contributions to political parties are connected to political lobby and risk of corruption and are therefore considered by all international organizations to be a key element of transparency and sustainability. Compliance is one of the recommended indicators of the United Nations Conference on Trade and Development and German Association for Financial Analysis and Asset Management. Complaints of stakeholders are closely associated with stakeholder engagement, which the European Academy of Business in Society and International Federation of Accountants considers to be an element of Corporate Governance performance. Gender balance should contribute to sustainable growth. However, the questionnaire has shown that Czech companies do not see female members of the CG 
as an important element of their success and performance. According to the questionnaire, reaching strategic objectives is considered the most significant indicator of corporate governance performance.

\section{Conclusion}

This paper presented the results of a questionnaire that sought to determine corporate governance key performance indicators in relation to corporate sustainability. It was found that the original set of twelve performance indicators can be substituted by only five key performance indicators. These indicators are therefore the key ones for corporate sustainability and accountability of corporate governance. Corporate governance performance is influenced by two factors: Relationship between Corporate Governance and Stakeholders and Strategy \& Compliance. Advanced statistical methods including multidimensional ones are suitable for modelling and constructing corporate performance indicators. However, this is just one approach. The indicators can also be determined heuristically, by applying some of the expertise methods.

Indicators of CG performance should become part of the code of CG. Indicators transform general best practices and recommendations into measurable goals. Corporate governance is closely linked with corporate reporting. Communication of CG practices and effectiveness may bring about several positive effects: it can improve negotiations with state and local authorities and other subjects, it can increase positive employee relationships with their company, and it can also increase attractiveness to potential investors and international cooperation and thereby achieve significant long-term economic effects and sustainability. Also, the EU corporate governance framework (European Commission, 2011) focuses on improving monitoring and the quality of explanations stated in the reports on CG to ensure sustainable growth. However, the Study on Monitoring and Enforcement Practices in Corporate Governance in the Member States (RiskMetrics Group, 2009) showed that the overall quality of reports on CG is unsatisfactory. Companies in the Czech Republic publish mostly only statutory information, rarely publishing data beyond the legal framework report (Kocmanová, Dočekalová and Hornungová, 2011). The solution is that information on CG practices and CG performance indicators should become part of corporate sustainability reporting. Corporate sustainability reports provide information about the economic, environmental, social and governance performance of a company. This is mostly a voluntary activity, but in Norway, Sweden, Australia, Great Britain and Italy, for example, it is mandatory by law. In companies that were forced by the law to adapt mandatory sustainability reporting, bribery and corruption has been reduced and these companies implement more ethical practices (Ioannou and Serafeim, 2011).

The main limitation of the research is the small number of respondents who took part in the questionnaire. Receiving $72 \%$ completed questionnaires can be considered a success, but from a statistical point of view it was a small set. Future research could therefore focus on broadening the basic set, carrying out the research in different areas and economic sectors and then comparing the results with companies operating abroad. 


\section{Acknowledgements}

This paper was supported by the Czech Science Foundation. Name of the project: Measuring Corporate Sustainability in Selected Sectors. Reg. No. 14-23079S.

\section{References}

Ayuso, S., Argandona, A. (2007). Responsible corporate governance: Towards a stakeholder board of directors? IESE Business School Working Paper No. 701. Retrieved June 8, 2014, from http://www.iese.edu/research/pdfs/di-0701-e.pdf.

Clark, V.L. (2004). SAS/STAT 9.1: User's guide. SAS Institute.

Committee on the Financial Aspects of Corporate Governance. (1992). Committee on the Financial Aspects of Corporate Governance Report with Code of Best Practice. (Cadbury Report). London: Gee Publishing. Retrieved September 10, 2014, from http://www.ecgi.org /codes/documents/cadbury.pdf.

Cranfield School of Management. (2009). Sustainable Value EABIS Research Project: Corporate Responsibility, Market Valuation and Measuring the Financial and Non-Financial Performance of the Firm. Retrieved June 17, 2014, from http://investorvalue.org/docs/EabisProjectFinal.pdf.

Demb, A., Neubauer, F. F. (1992). The Corporate Board: Confronting the Paradoxes. New York: Oxford University Press.

Donaldson, L., Davis, J. H. (1991). Stewardship Theory or Agency Theory: CEO Governance and Shareholder Returns. Australian Journal of Management, 16(1), 49-64.

DVFA. (2007). Key Performance Indicators (KPIs) for Extra-/Non-Financial Reporting. Retrieved June 17, 2014, from http://www.accreditedresearch.com/files/die_dvfa/kommissionen/non_financials/application/pdf/KPIs_Schriftenreihe_Final.pdf.

European Commission. (2011). Green paper: the EU corporate governance framework. Retrieved September 10, 2014, from http://eur-lex.europa.eu/legal-content/EN/TXT/HTML/?uri=CELEX:52011DC0164\&qid=1411649048116\&from=EN.

Gompers, P. A., Ishii, J. L., Metrick, A. (2001). Corporate governance and equity prices. National bureau of economic research. Retrieved September 10, 2014, from http://www.nber.org/papers/w8449.pdf.

Heracleous, L. (2001). What is the impact of corporate governance on organisational performance? Corporate Governance: An International Review, 9(3), 165-173.

Hřebíček, J., Soukopová, J., Štencl, M., Trenz, O. (2011). Integration of economic, environmental, social and corporate governance performance and reporting in enterprises. Acta Universitatis Agriculturae et Silviculturae Mendelianae Brunensis, 59(7), 157-166. Ioannou, I., Serafeim, G. (2011). The Consequences of Mandatory Corporate Sustainability Reporting. Working paper 11-100. Harvard Business School. Retrieved August 25, 2014, from http://www.hbs.edu/research/pdf/11-100.pdf.

IFAC. (2012). Investor demand for environmental, social and governance disclosures: Implications for professional accountants in business. Retrieved June 17, 2014, from http://viewer.zmags.com/publication/15a83b62\#/15a83b62/22. 
Jungman, C. (2006). The effectiveness of corporate governance in one-tier and two-tier board systems - evidence from the UK and Germany. European Company and Financial Law Review, 3(4), 426-474.

Kavalîr, P. (2005). Hodnocení corporate governance v České republice. Working Paper CES VŠEM. Retrieved June 18, 2014, from http://www.vsem.cz/ data/data/ces-soubory/workingpaper/gf_WPNo14.pdf.

Klírová, J. (2001). Corporate governance: správa a řizení obchodních společností. Praha: Management Press.

Kocmanová, A., Dočekalová, M. (2012). Construction of the economic indicators of performance in relation to environmental, social and corporate governance (ESG) factors. Acta Universitatis Agriculturaeet Silviculturae Mendelianae Brunensis, 60(4), 141-149.

Kocmanová, A., Dočekalová, M., Hornungová, J. (2011). Corporate Governance and Volutary Reporting in the Czech Republic Business Companies. In Creating Global Competitive Economies. 1. Milan, Italy: International Business Information Management Association (IBIMA), 2011. p. 1557-1571.

Kocmanová, A., Šimberová, I. (2012). Modelling of Corporate Governance Performance Indicators. Engineering Economics, 23(5), 485-495.

Malý, M., Theodor, M., Peklo, J. (2002). Řizení a správa společností: (Corporate governance). Praha: VŠKE.

OECD. (2008). Handbook on Constructing Composite Indicators. Methodology and User Guide. Retrieved March 1, 2014, from www.oecd.org/std/42495745.pdf.

OECD. (2004). Principles of Corporate Governance. Retrieved June 18, 2014, from http://www.oecd.org/dataoecd/32/18/31557724.pdf.

RiskMetrics Group. (2009). Study on Monitoring and Enforcement Practices in Corporate Governance in the Member States. Retrieved November 28, 2014, from http://ec.europa.eu/ internal_market/company/docs/ecgforum/studies/comply-or-explain-090923_en.pdf.

Růčková, P. (2008). Corporate Governance v České republice. Praha: Professional Publishing.

Shleifer, A., Vishny, R. W. (1997). A survey of corporate governance. Journal of Finance, 52(2), 737-783.

Solomon, J. Corporate governance and accountability ( $2^{\text {nd }}$ ed.). Hoboken: Wiley.

Škaloudová, A. (2010). Faktorová analýza. Charles University in Prague. Retrieved January 1, 2014, from http://userweb.pedf.cuni.cz/kpsp/skalouda/fa/.

UNCTAD. (2008). Guidance on Corporate Responsibility Indicators in Annual Reports. Retrieved June 17, 2014, from http://unctad.org/en/ docs/iteteb20076_en.pdf. 